\title{
Identification of Grip Profile for Hand Tool - A Preliminary Ergonomics Study
}

${ }^{1}$ Mohd H Ibrahim, ${ }^{2}$ Nor A Said, ${ }^{3}$ Ummi N Roslan and ${ }^{4}$ Aaina N Mohd A.

${ }^{1, S e n i o r ~ L e c t u r e r s, ~ F a c u l t y ~ o f ~ M a n u f a c t u r i n g ~ E n g i n e e r i n g ~ T e c h n o l o g y, ~ T A T I ~ U n i v e r s i t y ~ C o l l e g e, ~} 24000$ Kemaman, Terengganu, Malaysia

2,3, Lecturers, Faculty of Manufacturing Engineering Technology, TATI University College, 24000 Kemaman, Terengganu, Malaysia.

${ }^{4}$ Final Year 2017 Bachelor Student, Faculty of Manufacturing Engineering Technology TATI University College, 24000 Kemaman, Terengganu, Malaysia.

Correspondence Author: Mohd H Ibrahim. Faculty of Manufacturing Engineering Technology, TATI University College, 24000 Kemaman, Terengganu, Malaysia.

E-mail: habir@tatiuc.edu.my, Tel : +6098631192

Received date: 23 March 2018, Accepted date: 25 April 2018, Online date: 25 May 2018

Copyright: (C) 2018 Mohd H Ibrahim et al. This is an open-access article distributed under the terms of the Creative Commons Attribution License, which permits unrestricted use, distribution, and reproduction in any medium, provided the original author and source are credited.

\begin{abstract}
The use of tools is still widely valued in industries at various levels. The range of hand tools application varies from a simple task of filing tool to a complicated, complex and precision-demanding tasks such as that of surgical scalpels. Hence, it becomes highly essential to design the tool for 'comfort' from the perspective of user. The aim of this study is to perform a preliminary study of hand grip profile. Plastesine was used in order to mould hand profile prior to systematically dimensioning into CAD. Preliminary sample of 5 males and females were considered. It was noted that male grip profiles are larger than female grip profile. However, female grip profiles tend to show more variation. Further works is recommended by takings more samples that could provide more accurate statistical analysis in designing future hands tool.
\end{abstract}

Key words: Hand Tool, Grip Profile. Ergonomics Biomechanics

\section{INTRODUCTION}

Hand tools are widely used in many industrial tasks and most workers in manufacturing industry have to use them as a routine in their work activities. Activities involving on analyzing hand tools ranging from sophisticated to general traditional event such as musculoskeletal robotics modeling of hand exoskeleton considering the fingers joint angles (Hansen et al., 2018) and discomfort due to various type and sizes hand tools (Wibowo et al., 2016) respectively. Working with hand tools is associated with several health risks. Injuries causes by hand tools has been claimed to be costly, severe and frequent (Dianat et al., 2014). The appearance and design of tool is influenced by the human body, the materials available, and the tasks to be performed. Improvements in ergonomics characteristics of hand tools may be essential to reduce the risk of musculoskeletal disorders, as ergonomically designed hand tools cause users less harm, require less effort, and provide more comfort at work (Kim., 2012). A tool becomes "ergonomic" only when it fits the task and hand without causing awkward postures, harmful contact pressures, or other safety and health risks while performing works. Ergonomics is the science of work of how people performing task including tools, equipment and psychosocial aspects workplace. It is also the scientific discipline concerned with designing according to human needs, and the profession that applies theory, principles, data and methods to design products in order to optimize human well-being and overall system performance (Pheasant et al., 2006). In this mini research, a preliminary study of grip profile for hand tools should be conducted considering vital reasons as of the following literature.

\subsection{Cumulative Trauma Disorder:}

Cumulative Trauma Disorders, CTD, is a collective term for syndromes characterized by discomfort, impairment, disability or persistent pain in joints, muscles, tendons and other soft tissues, with or without physical manifestations. It is caused or aggravated by repetitive motions including vibrations, sustained or constrained postures, and forceful movements at work or leisure. Many different terms have been used to describe the observed events. For example, the syndrome has also been called carpal tunnel syndrome, over-use injury, cervicobrachial disorder, cumulative trauma injury, repetition strain injury, repetitive motion injury and rheumatic disease (Kroemer., 2001).

\subsection{Desiging of Hand Filing Tool:}

The process of designing and selecting the hand tools to provide a better fit for the user lies on the shoulders of human factor or ergonomists engineers. Consideration of human variation, minimum and maximum values are vital since this could cover sizes on actual application e.g. grip span (Ibrahim and Mohd A, 2017). For grip profile, the technique of measurement could be referred to method used in designing of handle using rapid prototyping technology (Simunic et al., 2013). This method used clay model to shape up hand's grip where force applied on wrist and hand was distributed accordingly. These parts of the process of designing hand's tools were for good ergonomics that contributing in reducing biomechanical stresses and decreasing the risk of cumulative trauma and carpal tunnel syndrome disorders of workers. Handles were also should be slip-resistant, either by material or by design. Designing hand tool was a complex tasks as it requirement considering not only functionality, quality, and reliability, but also their uses expectations and apprehensions (Kim, 2012).

\section{MATERIALS AND METHOD}

In order to design an ergonomics prototype tool handle, factor of human's hand size should be considered which are the grip span and profile. As the analysis of grip span of human hand had already been successfully studied (Ibrahim and Mohd A, 2017), this paper would continue to analyse on the grip profile as both (grip span and profile) are considered important in designing hand tools. In this study, the methodology to identify grip profile was according to Simunic et al (2013). where measurement of the grip profile was according to the clay model to get the hand profile. The force applied on wrist and hand was distributed by almost whole handgrip area to decrease pressure peaks in hand as the following Figure 2.1 . 


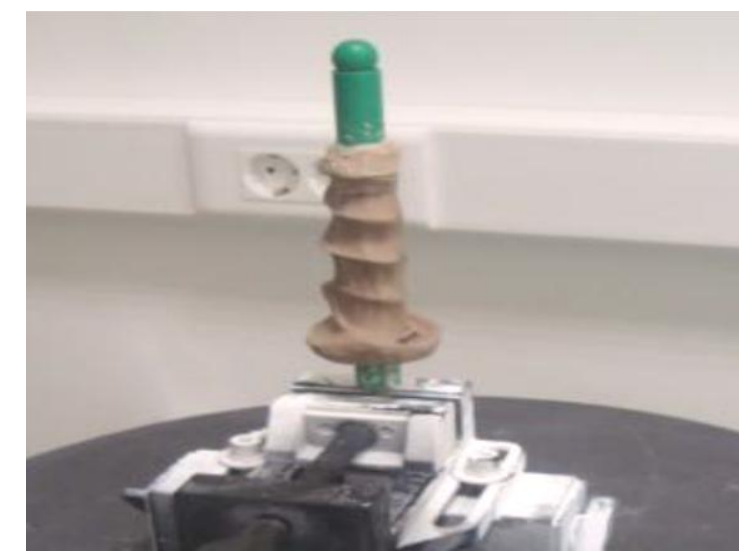

Fig. 2.1: Clay model of hand profile (Simunic et al., 2013).

Similar Simunic's model was implemented in order to duplicate profile of hand grip. However plastesine was used instead of clay as both are having similar physical properties which could be easily forced to deform. Therefore, this physical property facilitates to duplicate grip profile based on the hand's anatomic posture. Right hand grip would be used since right hand was commonly known to people as the majority anatomy habit in normal working condition. The photo of the methodology used in this research was as follows

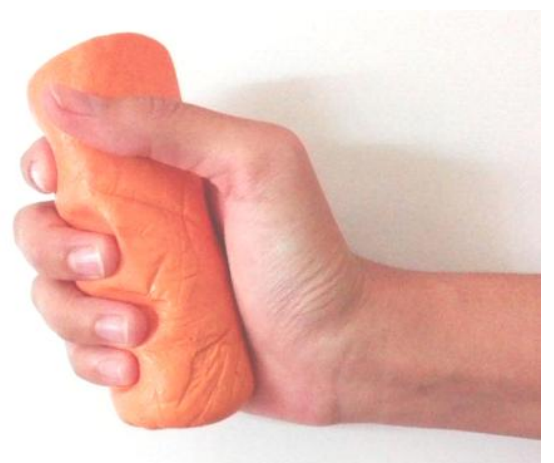

(a)

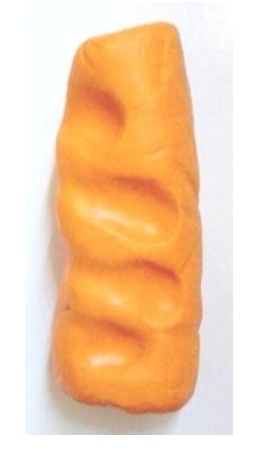

(b)

Fig. 2.2: Plastesine model of hand grip to form the grip profile

Further, the grip profiles from the deformed plastesine would be translated into the CAD which would generate the dimension accordingly. Detail dimensions of the grip profile would be recorded according to the following format (Figure 2.3). Finger length is represented by $Y_{i}$, while, finger depth is represented by $X_{\mathrm{i}}$.

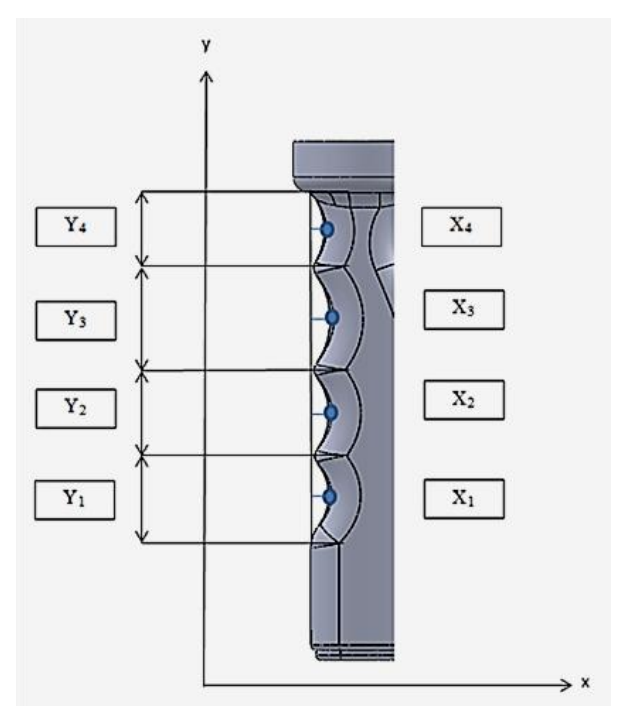

Fig. 2.3: CAD dimensions identification of grip profile

As this is the preliminary study, data were only taken from 5 males and females students respectively. Limited sample taken was due to difficult task of transferring dimensions from deformed plastesine to CAD drawing. 
Citation: Mohd H Ibrahim, Nor A Said, Ummi N Roslan and Aaina N Mohd A., 2018. Identification of Grip Profile for Hand Tool - A Preliminary Ergonomics Study. Australian Journal of Basic and Applied Sciences., 12(5): 8-11.

\section{RESULT AND DISCUSSION}

Detail measurement of all male and female students was taken and recorded as on the following Table 3.1 and 3.2 respectively.

Data measurement made for 5 male students showed that minimum depth of $\mathrm{X}_{4}, \mathrm{X}_{3}, \mathrm{X}_{2}$ and $\mathrm{X}_{1}$ was at $2.2,1.8,1.5$, and $1.4 \mathrm{~cm}$ respectively while the maximum was at 2.5, 2.4, 2.2 and $1.9 \mathrm{~cm}$ respectively. For the length of $\mathrm{Y}_{4}, \mathrm{Y}_{3}, \mathrm{Y}_{2}$ and $\mathrm{Y}_{1}$, the minimum value was $1.9,2.2,1.8$ and $1.6 \mathrm{~cm}$ respectively while the maximum was 2.4, 2.6, 2.4 and $1.9 \mathrm{~cm}$ respectively. The data showed that student number 3 represent the largest dimension while student number 1 represent the smallest dimension. There was also noted that student number 4 was also among the smallest dimension of $\mathrm{X}_{4}$.

Table 3.1: Data length and depth for male students

Table 3.1: Data length and depth for male students
\begin{tabular}{|l|l|l|l|l|}
\hline Student & & Length, cm & & \\
\hline \multirow{4}{*}{1} & $\mathrm{Y}_{4}$ & 1.9 & $\mathrm{X}_{4}$ & \\
\cline { 2 - 5 } & $\mathrm{Y}_{3}$ & 2.2 & $\mathrm{X}_{3}$ & \\
\cline { 2 - 6 } & $\mathrm{Y}_{2}$ & 1.8 & $\mathrm{X}_{2}$ & \\
\cline { 2 - 5 } & $\mathrm{Y}_{1}$ & 1.6 & $\mathrm{X}_{1}$ & 1.2 \\
\hline
\end{tabular}

2

\begin{tabular}{|l|l|l|}
\hline $\mathrm{Y}_{4}$ & 2.2 & $\mathrm{X}$ \\
\hline $\mathrm{Y}_{3}$ & 2.4 & $\mathrm{X}_{3}$ \\
\hline $\mathrm{Y}_{2}$ & 2.2 & $\mathrm{X}_{2}$ \\
\hline $\mathrm{Y}_{1}$ & 1.8 & $\mathrm{X}$ \\
\hline
\end{tabular}

\begin{tabular}{|l|l|}
\hline $\mathrm{X}_{4}$ & 2.4 \\
\hline $\mathrm{X}_{3}$ & 2.3 \\
\hline $\mathrm{X}_{2}$ & 2.0 \\
\hline $\mathrm{X}_{1}$ & 1.7 \\
\hline
\end{tabular}

3

\begin{tabular}{|l|l|l|l|}
\hline$Y_{4}$ & 2.4 & $X_{4}$ & 2.5 \\
\hline$Y_{3}$ & 2.6 & $X_{3}$ & 2.4 \\
\hline$Y_{2}$ & 2.4 & $X_{2}$ & 2.2 \\
\hline$Y_{1}$ & 1.9 & $X_{1}$ & 1.9
\end{tabular}

\begin{tabular}{|c|c|c|c|c|}
\hline \multirow{4}{*}{4} & $\mathrm{Y}_{4}$ & 2.1 & $\mathrm{X}_{4}$ & 2.2 \\
\hline & $\mathrm{Y}_{3}$ & 2.4 & $X_{3}$ & 2.1 \\
\hline & $\mathrm{Y}_{2}$ & 2.2 & $\mathrm{X}_{2}$ & 1.9 \\
\hline & $\mathrm{Y}_{1}$ & 2.0 & $\mathrm{X}_{1}$ & 1.8 \\
\hline \multirow{4}{*}{5} & $\mathrm{Y}_{4}$ & 2.2 & $\mathrm{X}_{4}$ & 2.4 \\
\hline & $\mathrm{Y}_{3}$ & 2.3 & $\mathrm{X}_{3}$ & 2.2 \\
\hline & $\mathrm{Y}_{2}$ & 2.0 & $\mathrm{X}_{2}$ & 1.9 \\
\hline & $\mathrm{Y}_{1}$ & 1.8 & $\mathrm{X}_{1}$ & 1.7 \\
\hline
\end{tabular}

\begin{tabular}{|l|l|}
\hline Minimum value & \\
\hline Maximum value & \\
\hline
\end{tabular}

The data measurement made for 5 female students showed that minimum depth of $\mathrm{X}_{4}, \mathrm{X}_{3}, \mathrm{X}_{2}$ and $\mathrm{X}_{1}$ was at $1.8,1.4,1.2$ and $1.0 \mathrm{~cm}$ respectively while the maximum was at $2.2,1.8,1.6$ and $1.4 \mathrm{~cm}$ respectively. Measurement on student number 1 and 4 also showed at the minimum value of $\mathrm{X}_{4}$ which was $1.8 \mathrm{~cm}$. For the length of $\mathrm{Y}_{4}, \mathrm{Y}_{3}, \mathrm{Y}_{2}$ and $\mathrm{Y}_{1}$, the minimum value was $1.5,2.0,1.5$ and $1.4 \mathrm{~cm}$ while the maximum was $2.0,2.2,1.8$ and $1.6 \mathrm{~cm}$ respectively.

Table 3.2: Data length and depth for female students

\begin{tabular}{|c|c|c|c|c|}
\hline Student & & Length, $\mathrm{cm}$ & & Depth, cm \\
\hline \multirow{4}{*}{1} & $\mathrm{Y}_{4}$ & 1.5 & $\mathrm{X}_{4}$ & 1.8 \\
\hline & $\mathrm{Y}_{3}$ & 2.0 & $\mathrm{X}_{3}$ & 1.5 \\
\hline & $\mathrm{Y}_{2}$ & 1.7 & $\mathrm{X}_{2}$ & 1.2 \\
\hline & $\mathrm{Y}_{1}$ & 1.5 & $\mathrm{X}_{1}$ & 1.0 \\
\hline \multirow{4}{*}{2} & $\mathrm{Y}_{4}$ & 1.8 & $\mathrm{X}_{4}$ & 2.0 \\
\hline & $\mathrm{Y}_{3}$ & 2.2 & $\mathrm{X}_{3}$ & 1.6 \\
\hline & $\mathrm{Y}_{2}$ & 1.7 & $\mathrm{X}_{2}$ & 1.4 \\
\hline & $\mathrm{Y}_{1}$ & 1.5 & $\mathrm{X}_{1}$ & 1.3 \\
\hline
\end{tabular}

\begin{tabular}{|c|c|c|c|c|}
\hline \multirow{4}{*}{3} & $\mathrm{Y}_{4}$ & 2.0 & $\mathrm{X}_{4}$ & 2.2 \\
\hline & $\mathrm{Y}_{3}$ & 2.2 & $\mathrm{X}_{3}$ & 1.8 \\
\hline & $\mathrm{Y}_{2}$ & 1.8 & $\mathrm{X}_{2}$ & 1.6 \\
\hline & $\mathrm{Y}_{1}$ & 1.6 & $\mathrm{X}_{1}$ & 1.4 \\
\hline \multirow{4}{*}{4} & $\mathrm{Y}_{4}$ & 1.5 & $\mathrm{X}_{4}$ & 1.8 \\
\hline & $\mathrm{Y}_{3}$ & 2.1 & $\mathrm{X}_{3}$ & 1.6 \\
\hline & $\mathrm{Y}_{2}$ & 1.7 & $\mathrm{X}_{2}$ & 1.3 \\
\hline & $\mathrm{Y}_{1}$ & 1.4 & $\mathrm{X}_{1}$ & 1.0 \\
\hline \multirow{4}{*}{5} & $\mathrm{Y}_{4}$ & 1.7 & $\mathrm{X}_{4}$ & 1.8 \\
\hline & $\mathrm{Y}_{3}$ & 2.0 & $\mathrm{X}_{3}$ & 1.4 \\
\hline & $\mathrm{Y}_{2}$ & 1.5 & $\mathrm{X}_{2}$ & 1.2 \\
\hline & $\mathrm{Y}_{1}$ & 1.4 & $\mathrm{X}_{1}$ & 1.0 \\
\hline
\end{tabular}

\begin{tabular}{|l|l|}
\hline Minimum value & \\
\hline Maximum value & \\
\hline
\end{tabular}

In general, this preliminary study showed that male students represented larger sizes of grip compared to female. This normal fact is being exhibited by other researchers as well such as Wickens et al. (2014). The analysis also showed that male data be likely had less variation among the students as the minimum and 
maximum dimension noted by only one student respectively. Female data showed more variation among the students, however the smallest and the largest dimension was in general dominant by student number 5 and number 3 respectively. On top of that it was emphasized to the urgency of separating database according to gender data base (Rios et al., 2016) as females tend to expose more toward injuries in related to ergonomics factors (Rios et al., 2017).

\section{Conclusion and Recommendation:}

As being mentioned earlier, this was a preliminary study of grip profile. In general, methodology used in this work was considered fundamental and dimension obtained were roughly estimated. This was in line with the ergonomics traditional evaluation of hand tools where measurement methods should consider in broader area of physical, physiological or psychophysical (Kadefors et. al., 1993). Therefore, it is advisable to conduct a detail study where dimensions taken are to be translated / transferred more accurately such as to digitize model using suitable software (Harih and Dolšak, 2013). This work could be futher improved by producing prototype that could reflect detail dimensions taken. For the sample size, this study should consider taken more sample populations as this would be statistically presentable. Sample size 30 of is considered statistically acceptable reflecting statistics value such as minimum, maximum, average and standard deviation. This statistical value could be further applied in designing and fabricating activities in line with the significantly expanding international research area in biomechanics, biomechanical engineering and biomaterials (Mahmud, 2016).

\section{REFERENCES}

Dianat, I., M. Nadaei, M.A.M. Nezami, 2015. The effects of tool handle shape on hand performance, usability and discomfort using masons' trowels. International Journal of Industrial Ergonomics, 45: 13-20.

Hansen, C., F. Gosselin, K.B. Mansour, P. Devos, F. Marin, 2018. Design-validation of a hand exoskeleton using musculoskeletal modeling Applied Ergonomics, 68: 283-288.

Harih, G and B. Dolšak, 2013. Tool-handle design based on a digital human hand model. International Journal of Industrial Ergonomics, 43(4): 288-295.

Ibrahim, Mohd H and A. Mohd, N. Aainaa, 2017. Australian Journal of Basic and Applied Sciences, 11(9): 131-135.

Kadefors, R., A. Areskoug, S. Dahlman, A. Kilbom and J. Öster, 1993. An approach to ergonomics evaluation of hand tools. Applied Ergonomics, 24(3): 203-211.

Kim, B.J., 2012. Effect of Ergonomic Design Changes in Hand Tools on Physiological Cost and Subjective Ratings. International Journal of Occupational Safety and Ergonomics, 18(2): 267-277.

Kroemer, K.H.E., 2001. Cumulative trauma disorders: Their recognition and ergonomics measures to avoid them. Applied Ergonomics, 20(4): 274-280.

Mahmud, J., 2016. Keynote Speech in Biomechanics: Analysis and Benchmarking of Indexed Publications in Malaysia and South East Asia. Journal of Medical and Bioengineering, 5(2): 103-107.

Pheasant, S. and C.M. Haslegrave, 2006. Bodyspace : Anthropometry, Ergononmics And The Design Of Work. Third Edition, CRC Press, Taylor \& Francis Group Florida.

Rios, F.C., W.K. Chong and D. Grau, 2017.The need for detailed gender-specific occupational safety analysis. Journal of Safety Research, 62: 53-62.

Rios, F.C., W.K. Chong and D. Grau, 2016. Women and Accidents: The Need to Separate Gender Database. Procedia Engineering, 145 : 662-669.

Simunic, N., N. Mustapic, D. Bursac, 2013. Ergonomic Design Handle Using Rapid Prototyping Technology. $5^{\text {th }}$ International Conference ERGONOMICS.

Wibowo RKK. and P. Soni, 2016. Farmers'Injuries, Discomfort and Its Use in Design of Agricultural Hand Tools: A Case Study from East Java, Indonesia. Agriculture and Agricultural Science Procedia, 9: 323-327.

Wickens, C.D., J. Lee, S.E. Gordon, 2014. Engineering Anthropometry and Work-Space Design, An Introduction to Human Factors Engineering (2 Edition). Pearson Education. 